\title{
USING THE "DASH" (DUPLICATED ANSWER SHEETS) METHOD IN IMPROVING STUDENTS' READING COMPREHENSION
}

\author{
Bahrun Amin \\ English Education Department, Faculty of Teacher Training and Education \\ Muhammadiyah University of Makassar \\ bahrunamin@unismuh.ac.id
}

\begin{abstract}
This study aims at finding out to what extent DASH method improves students' reading comprehension and how good the students' improvement regarding their reading comprehension after taught through DASH method. This study was conducted at SMAN 1 Tanete Rilau, Barru Regency. The study used pre-experimental design involving only one class to observe, out of two hundred-eighty population of eleventh grade students of IPAII classes at SMAN-1 Tanete Rilau in academic year 2014/2015. The technique sampling was cluster random sampling. The instruments of collecting data used in this study were multiple choice and essay which were used to measure the students' comprehension in reading. Based on the data collected from the students showed that the post-test value is higher than pre-test table, so the null hypothesis is rejected. It means there is an influence of "DASH" (Duplicated Answer Sheets) method on student reading ability. So the students have responsibility and feel enjoy the learning process. It means that can "DASH" (Duplicated Answer Sheets) method be used as one of the alternative to teach reading. Further study is suggested to conduct the investigation of other teaching method or strategy that can be applied by teacher to encourage their student in reading comprehension.
\end{abstract}

Keywords: DASH Method, Reading Comprehension

\section{INTRODUCTION}

Language is one of the most important things in communication and it is used as a tool of communication among the nations in all over the world. As an international language, English is very important and has many interrelationships with various aspects of life owned by human being.

English is an international language; beside that English means of communication. English has important position in every aspect of life, it is not only in education but also in business, social, tourism, etc. The importance of English can be seen from other side. Nowadays many things have been written printed in English i.e.; magazine, newspaper, and scientific book.

In English, English focused on four basic skills, namely; listening, reading, speaking and writing. The reading skill became very important in the education field, students needed to be exercised and trained in order to have a good reading 
skill. In education English has been chosen as one of the subject that should be mastered by the student; in junior high school, senior high school, and university level.

In reading, to comprehend the text the readers should be able to manage every part of the text, because it is easy to gain the comprehension in reading when the readers are able to organize the text. Sometimes, they may used dictionary to get good comprehension in reading.

The most often become to complain is the teachers ability in applying appropriated approaches, methods, strategies or techniques in teaching or learning. So, many students are not interest in learning English. Therefore, the English teacher suggested in order to be able to master the method, such as, Nababan (1991: 4) notices that a qualified teacher is the teacher who is able to suit best method or technique to the material that is being taught.

According to Kustaryo (1988:2) it is certainly not easy to present the English reading for Indonesian students whose language system is different. Reading is a complex process which involves not only the read the text but also their experience to comprehend it. Because of its complexity, many teachers of English at junior and senior high school find difficulties in all teaching reading and prefer teaching structure to reading.

\section{DUPLICATED ANSWER SHEETS (DASH) METHOD}

This approach is used to analyze comprehension of reading texts via an innovative research design called the Duplicated Answer Sheets (DASH) Method. The DASH method is distinctive, inasmuch as it allows researchers to test students' performance (reading comprehension) using dictionaries in chunks of time.

To investigate the effect of dictionary use on reading among learners of different proficiency levels, we will be used a reading comprehension test with a multiple-choice format developed by a local test service center. The format of the test was patterned after a nationwide General English Proficiency test used in measuring reading comprehension, with questions consisting of one correct item and three distractors. Although there are some concerns when using a multiple- 
choice format in vocabulary tests and reading comprehension (see Nation, 1990; Peirce, 1992), it was used here for its overriding convenience of administration and relative ease of analysis (Wesche \& Paribakht, 1996). The test scores were used to indicate the effect of dictionary use on the participants' overall reading comprehension. The DASH method was used to score the test, because it allows for incremental scoring over extended periods of time.

The DASH method consists of multiple carbon-copy style answer sheets, which can be peeled off off as a way to record student scores in timed increments. In our case, participants' score sheets consisted of six different answer sheets, so that the scores could be collected every 15 min during the 90-min test (at the 15-, 30-, 45-, 60-, 75-, and 90-min marks). In other words, each answer sheet peeled off and collected represented the test score that a subject gained during the allotted test time. Since participants were able to change their answers on previously answered questions, each test score was treated as a score independent of the other five that were collected.

Variables such as textual knowledge and ease or difficulty of a text can affect readers' performance on comprehension tests. Investigating the time effect of dictionary use on learners of different proficiency levels using a traditional test method would require the researchers to give the participants six different tests (one requiring $15 \mathrm{~min}$ to complete, another requiring $30 \mathrm{~min}$, another requiring 45 min, etc). In addition, even with an extensive effort to modify such tests with the aim of achieving test similarity between the six versions, factors such as text difficulty and topical knowledge would likely have a considerably negative effect on the results. It might be argued that, by employing identical tests repetitively, the text difficulty variance could be addressed. However, researchers would then be faced with the practice effect caused by readers' repeated exposure to the same texts and questions, not to mention the fact that this is not remotely similar to how reading is done or tested in more natural settings. Additionally, if learners are indeed learning, they logically should score higher on subsequent tests. And, regarding topical knowledge, although there are particular readability formulas, such as the Lix formula (Knight, 1994), there is always the problem posed by used 
different test texts, because different learners inevitably have different strengths as related to content (background) knowledge. The DASH method allowed us to analyze test scores using the same texts in relation to the time effect. By obtaining the mean scores of the participants in each collection, the factor of individual textual knowledge or background knowledge could thus be averaged out, leaved the scores and make for a clean time effect.

In addition to the benefit of the clean time effect associated with using the DASH method, the traditional method of giving six different tests at 15, 30, 45, 60,75 , and $90 \mathrm{~min}$, respectively, would consist of testing participants for a total of $315 \mathrm{~min}$ to complete such a study. Irrespective of any variability in text difficulties, the diminishing returns on reliability and validity because of participants' affective conditions (such as sheer exhaustion and boredom) and environmental stability in the over-5-hr, nonstop testathon would be significant. By incorporating the DASH method in this study, only one reading assessment test was needed, because the other variables could be easily controlled (leaving the variable of time and learners' proficiency levels to be investigated with dictionary use while reading). Besides the time-saving effect of the DASH method, it was also economical, because it uses duplicate carbon copies.

The participants were provided with the same testing material during the 90-min test. Prior to the test administration, the participants were informed of the purpose of the study and reassured that their test scores would not be used as a determining factor in their English class grade. This was done as a means to lower students' reading anxiety while taking the test (Saito, Garza, \& Horwitz, 1999), with the hope that they would, nevertheless, try their best to answer the questions.

The same 90-min test was given to both groups of students using the DASH method as a scoring tool. The test sections were collected as intended at the 15-, 30-, 45-, 60-, 75-, and 90-min marks.

The participants with dictionary access were allowed to choose the kind of dictionary they were familiar using and were asked on the answer sheet to indicate the type of dictionary they had used during the test: monolingual (English only), bilingual (English with equivalent Chinese translations), or a dual-bilingual dictionary that contains English entries with English definitions and their literal 
Chinese translations. The participants were also told and encouraged to look up the unfamiliar vocabulary they encountered, to fulfill the aims of this study, and they were required to underline the words they looked up. Through the researchers' on-site observation, informal posttest interviews with the participants in the dictionary group, and the underlined words on the question sheets, it was clear that the with-dictionary groups had consulted dictionaries extensively throughout the test as a means to identify vocabulary items with which they were unfamiliar.

\section{Figure 1: The DASH Method}

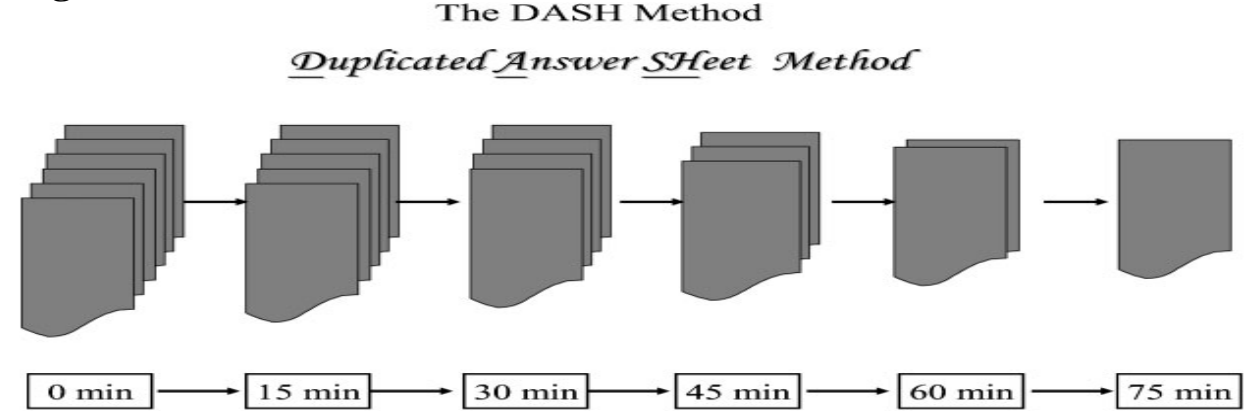

\section{CONCEPT OF READING}

According to Elizabeth (2008:1-2), reading is the process of constructing Meaning from print and from other symbol. Reading involves not just the print and the illustrations, but also readers bringing to the process their knowledge of the world and their past experiences.

According to McCracken and Walcutt (1969:4) Reading is to get information of some sort from the printed page. But since we get information in the same way from spoken language, this proposal does not define reading in a way that distinguishes it from talking.

a. Law and Brothers (1982:89) states that reading is ability to recognize word, phrases, sentences, and paragraphs.

b. Anderson et al.( 1985) states that reading is the process of constructing meaning from written texts. 
c. Heldi Byrnes (1998:7) state that reading is an interactive process that goes on between the readers and text, resulting in comprehension.

d. Harris et all (1980:5) define reading as a process of meaning elaboration or thinking in relation to written symbols. The recognition and comprehension Written symbols are influenced by reader's perception skill, experience, language background, mind sets and reasoning abilities as they anticipate meaning on the bases of what has read.

e. Herbert J. Walberg (2000:6), Reading is about understanding written texts. It is a complex activity that involves both perception and thought.

f. Lawrence W. Carrillo (1976:1-3), reading is not something that happens to you automatically when you arrive at a certain chronological age. Given the correct environment, reading may be acquired at many stages of growth and development. Reading is actually a cohesive set of skills that must be carefully presented in an orderly sequence to be efficiently used then and later.

g. A broader definition presented by Rubin (1982:8) is that "reading is the bringing and the getting of meaning from the printed page". This definition implies that readers bring their background, experiences, and emotion into play. Consequently, upset students will bring their feelings into the act of reading, and this kind of situation will affect the reading process.

Furthermore, Dolores in Aulia (2005:7) classified reading into three kinds, namely: reading aloud, silent reading, and speed reading. Reading Aloud is important and the students should be taught to read aloud. Reading aloud is a kind of reading where a reader expressed orally every word in the text. The purpose of reading aloud is to improve the students' ability in pronouncing the words, stressing the words, and having a good intonation about every sentence in the passage. Silent reading is reinforcing the readers to find out the meaning of the words. This kind of reading leads the readers to the better comprehension. This reading is skill to criticize what is written, to discuss written meaning and to draw Inference and conclusion as to express well as to tell new ideas on the basic of 
what is read. To develop the students understanding in the silent reading, we give them short reading passage at the beginning and ask question after words. Reading fast used to improve speed and comprehension in reading. This skill is very important for students. This skill must run the side with the main purpose of reading that is comprehension. The role of reading speed, depends on the kinds of reading material. The rate of speed is a reading scientific material. This speed rate if reading narrative material will be different with other material.

The process of teaching reading is supposed to promote reading comprehension of the students. Hornby (1974:711) explain that reading is the act of one who reads; knowledge, ESP, of books: the ways in which something is interpreted, while comprehension is the act of understanding, the ability of the mind to understand. Procter in Rahman (1988:6) Evison in Tahir (2001:8) explain that comprehension is the mind's power of understanding, or the ability to understand.

Elizabeth et. All (2002:14) explain that comprehension is an active process in the construction of meaning. Comprehension is the process of deriving meaning from connected text. It involves word knowledge (vocabulary) as well as thinking and reasoning. Therefore, comprehension is not a passive process, but an active one.

Comprehension is a special kind of thinking process. The reader comprehends by actively constructing meaning internally from interacting with the material that is read (Anderson and Pearson in Alexander, (1993:160). From the point of view given above, it can be concluded that reading is an active thinking process where the reader tries to gain information given by the author and understands what actually the purpose of author.

Comprehension is understanding the meaning of what is the read from the print, illustrations, layout and design (Elizabeth, 2008:190).

Reading comprehension is the activity between the reader and the writer's idea. Where the writer sends his/her idea in the written symbols and then the reader catches the idea it. Reading is on activity cognitive process of interactive 
with printing and monitoring comprehension to establish meaning (Kustaryo in Abdullah, 2006:22)

According to Hornby in Lusiana (2007:10) reading comprehension means reading with the power of understanding of the printed symbols. Reading comprehension is the goal instruction in reading and recognition is a means to help achieve that goal (Choate, 1995:153).

\section{RESEARCH METHOD}

The research employed a pre-experimental method with one class, pretest and posttest design. The research employed a pre-experimental method with one class pre-test and post-test design. Before giving the treatment, The researcher given pre-test. It gave to know how effective of Duplicated Answer Sheet (DASH) method toward students' in reading comprehension.

The population of this research is the eleventh grade students of the SMAN 1 Tanete Rilau, Barru Regency in 2014/2015 academic year, there are population of students consist of fifth class; each class consist of 30-35 students. The total population is consists of 280-300 students. The researcher took randomly about 35 students from the population of eleventh grade students in academic year 20142015. This sample was chosen by using simple random sampling technique. The students of experimental class will be taught by Duplicated Answer Sheets (DASH) method.

\section{FINDINGS AND DISCUSSION}

\section{Implementation of Duplicated Answer Sheets Method}

The activity in treatment is the implementation of the lesson plan. Firstly, the researcher introduced about material and gave explanation about reading comprehension by used DASH method. Secondly, the researcher asked to students what their difficulties about the reading comprehension used DASH method and gave the text as a sample and then students read. Thirdly, the researcher gave essay test and each student again asked their difficulties about the text. Fourthly, 
the researcher gave essay test again by used DASH method, students repeated and corrected.

It can be understood if considering the class situation during the teaching process. Only few of them show their interest in learning and following the teaching process. The others look bored and have no mood in learning process. They are not noise and just sitting in their chair and calm in the class. It shows that the teaching process during treatment is fairly good.

The result of revision treatment to resolve the difficulty to accomplish of the text is besides providing some interesting topics and also new, the researcher also reforms many aspects such as more relaxed in teaching, gave the students motivation, raises the voice, and resurrects the class management, time management. The researcher also gave direction and the students chance to ask the question, explains the students' mistakes in reading clearly so didn't happen misunderstood and guided the students in reading well.

\section{The Extent of DASH Method in Improving Students' Reading Comprehension}

From the result of the tests, the researcher will managed than to classify the learners' achievement, the good ones and the bad ones in Learning Reading Comprehension. Then, the researcher used criterion research that the correct answer got 1 score for each multiple choice test item and used criterion research that the correct answer got 4 score for each essay test item. The total numbers of those items were 25 . So the total scores of the tests are 100 for the learners who answer all the tests correctly, and for the learners who answers all the tests wrongly will get zero score (0). 
Table 2: The Mean Score of the Students' Reading Comprehension

\begin{tabular}{|c|c|c|c|c|c|}
\hline \multirow{2}{*}{$\begin{array}{c}\text { SUBJECT } \\
\mathrm{S}\end{array}$} & \multicolumn{2}{|c|}{$\begin{array}{c}\text { THE STUDENTS' } \\
\text { SCORE }\end{array}$} & \multicolumn{2}{|c|}{ CLASSIFICATION } & \multirow{2}{*}{$\begin{array}{l}\text { MEAN } \\
\text { SCORE }\end{array}$} \\
\hline & PRE-TEST & $\begin{array}{l}\text { POST- } \\
\text { TEST }\end{array}$ & PRE-TEST & POST-TEST & \\
\hline S-1 & 53 & 65 & POOR & FAIR & 59 \\
\hline S-2 & 53 & 70 & POOR & FAIRLY GOOD & 61,5 \\
\hline S-3 & 40 & 80 & POOR & GOOD & 60 \\
\hline S-4 & 45 & 75 & POOR & FAIRLY GOOD & 60 \\
\hline S-5 & 53 & 70 & POOR & FAIRLY GOOD & 61,5 \\
\hline S-6 & 40 & 78 & POOR & GOOD & 59 \\
\hline S-7 & 58 & 68 & FAIR & FAIRLY GOOD & 63 \\
\hline S-8 & 55 & 60 & POOR & FAIR & 57,5 \\
\hline S-9 & 50 & 73 & POOR & FAIRLY GOOD & 61,5 \\
\hline S-10 & 53 & 65 & POOR & FAIR & 59 \\
\hline S-11 & 50 & 68 & POOR & FAIRLY GOOD & 59 \\
\hline S-12 & 48 & 78 & POOR & GOOD & 63 \\
\hline S-13 & 45 & 60 & POOR & FAIR & 52,5 \\
\hline S-14 & 48 & 68 & POOR & FAIRLY GOOD & 58 \\
\hline S-15 & 53 & 73 & POOR & FAIRLY GOOD & 63 \\
\hline S-16 & 53 & 65 & POOR & FAIR & 59 \\
\hline S-17 & 43 & 68 & POOR & FAIRLY GOOD & 55,5 \\
\hline S-18 & 30 & 65 & VERY POOR & FAIR & 47,5 \\
\hline S-19 & 60 & 68 & FAIR & FAIRLY GOOD & 64 \\
\hline S-20 & 38 & 70 & POOR & FAIRLY GOOD & 54 \\
\hline S-21 & 45 & 80 & POOR & GOOD & 62,5 \\
\hline S-22 & 35 & 75 & VERY POOR & FAIRLY GOOD & 55 \\
\hline $\mathrm{S}-23$ & 50 & 75 & POOR & FAIRLY GOOD & 62,5 \\
\hline $\mathrm{S}-24$ & 58 & 78 & FAIR & GOOD & 68 \\
\hline S-25 & 53 & 75 & POOR & FAIRLY GOOD & 64 \\
\hline S-26 & 40 & 73 & POOR & FAIRLY GOOD & 56,5 \\
\hline S-27 & 50 & 70 & POOR & FAIRLY GOOD & 60 \\
\hline S-28 & 43 & 75 & POOR & FAIRLY GOOD & 59 \\
\hline S-29 & 58 & 73 & FAIR & FAIRLY GOOD & 65,5 \\
\hline $\mathrm{S}-30$ & 45 & 65 & POOR & FAIR & 55 \\
\hline S-31 & 43 & 80 & POOR & GOOD & 61,5 \\
\hline S-32 & 53 & 73 & POOR & FAIRLY GOOD & 63 \\
\hline S-33 & 50 & 78 & POOR & GOOD & 64 \\
\hline S-34 & 50 & 65 & POOR & FAIR & 57,5 \\
\hline S-35 & 53 & 78 & POOR & GOOD & 65,5 \\
\hline $\begin{array}{l}\text { TOTAL } \\
\text { SCORE }\end{array}$ & 1694 & 2500 & & & 1268 \\
\hline $\begin{array}{l}\text { MEAN } \\
\text { SCORE }\end{array}$ & 48,4 & 71,4 & POOR & FAIRLY GOOD & 36,2 \\
\hline
\end{tabular}


The table above shows that there is The Extent of DASH Method in Improving Students' Reading Comprehension is enough significant. It's proved by seen the achievement of the students from the pre-test and post-test. The mean score of pre-test is 48,4 , and after giving post-test, the mean score become 71,4 . It means that there is improve.

\section{Result of the Students' Improvement in Reading Comprehension}

The improvement of the students' reading comprehension, which focused on time spent as variables in the eleventh class of SMAN 1 Tanete Rilau as result of the students' assessment of pre-test and post-test can be seen clearly in the following table:

Table 4.2: The Improvement of the Students' Reading Comprehension

\begin{tabular}{|c|c|c|c|c|}
\hline \multirow{2}{*}{ NO } & \multirow{2}{*}{ SCORE } & \multicolumn{2}{|c|}{ THE STUDENTS' SCORE } & IMPROVEMENT (\%) \\
\cline { 3 - 5 } & & PRE-TEST & POST-TEST & PI-PII (\%) \\
\hline 1 & TOTAL SCORE & 1694 & 2500 & 47,5 \\
\hline 2 & MEAN SCORE & 48,4 & 71,4 & 47,5 \\
\hline
\end{tabular}

The table above is clearly indicates the students' improvement in reading comprehension. We can see that in pre-test mean score $(48,4)$ classified as poor. It improves to be good classification which the mean score is $(71,4)$ in post-test, whereas improvement of the students' reading comprehension through DASH method in pre-test to post-test $(47,5 \%)$.

Finally, after passes several processes in pre-test and post-test which consisted of 4 meetings, the result of the data analysis through the reading test shows that the students' reading comprehension in terms of time spent improved significantly. It is indicated by the result of the students' mean score.

\section{CONCLUSION}

After analyzing the findings, it can be concluded that the extent of DASH method in improving the students' reading comprehension at the eleventh grade students of SMAN 1 Tanete Rilau, Barru Regency is The students' score the pretest is 48,4 and in the last treatment is 71,4 the students' can able to answer and comprehending the text. Actually, DASH method influencing students' score 
reading comprehension and enough significant. The improvement of the students' reading comprehension at the eleventh grade students of SMAN 1 Tanete Rilau, Barru Regency through DASH method is the mean score of reading comprehension in pre-test is 48,4 and in post-test is 71,4 , where the improvement of pre-test to post-test is 23,0 . So the student' score improve until $47,5 \%$.

\section{BIBLIOGRAPHY}

Alderson, J. Charles. 2000. Assessing Reading. Cambridge, England: Cambridge University Press.

Anderson and Person. 1984. Teaching Reading. Third Edition: Boston: J. Estill Alexander.

Arikunto, Suharsimi. 2005. Prosedur Penelitian. (suatu pendekatan praktik, Edisi revisi IV). Jakarta: PT RINEKA CIPTA.

Arikunto, Suharsimi. 2010. Prosedur Penelitian. (suatu pendekatan praktik, Edisi revisi IV). Jakarta: PT RINEKA CIPTA.

Arsyad, Azhar. 1994. Dasar-Dasar Penguasaan Bahasa Inggris Lewat Your Basic Vocabulary. Makassar: Pustaka Pesantren UP.

Bahleuwi, Ajie. 2010. Instant Vocabulary. Yogyakarta: Kaysa Media.

Basri D, Muhammad. 2007. Fundamental of Research Methodology. Makassar.

Best, John. W. 1977. Research in Education. Third Edition: New Jersey: PrenticeHall, Inc., Englewood Cliffs.

Bull, Victoria. 2008. Oxford Learner's Pocket Dictionary. Fourth Edition: New York: Oxford University Press.

Carrillo, Lawrence. 1975. Teaching Reading. New York: St. Martin Press.

Echol, John M, and Shadily Hassan. 2005. Kamus Inggris Indonesia. Jakarta: Gramedia.

Elizabeth, et. All. 2000. Teaching Reading. Chicago: Chicago University Press.

Hamra Arifuddin \& Syatriana Eny. 2010. Developing a Model of Teaching Reading Comprehension for EFL Students. TEFLIN Journal.

Kustaryo S. 1988. Reading Technique for College Students. Jakarta: P2 LPTK. 
Lestary, Dhevie. 2011. Influence of Think-Pair-Share Technique on the Students' Reading Ability at the Eighth Grade Students of SMP PGRI Batuceper Tangerang. Tangerang: Setia Budhi Rangkasbitung University.

Mahdalena, Leny. 2007. Effects of Pre-Questioning on the Reading Comprehension Achievement of the Second Grade Students at SMAN-2 Jekan Raya in Academic Year 2006/2007. Palangkaraya: Palangkaraya University.

Nilawati, Aulia. 2005. Improving reading comprehension by using Directed Activities Related to Text. Makassar.

Nunan David, Eggewn, Paul and Kauchack, Donald. 1989. Method for Teaching, a skill Approach. Ohio:Merril Publishing Company.

Nunan, David. 1991. Language Teaching Methodology. New York: Prentice hall.

Shieh,Wenyuh \& Freiermuth Mark R. 2010. Using the DASH Method to Measure Reading Comprehension. TESOL Quarterly.

Sugiyono. 2013. Cara Mudah Menyusun: Skripsi, Tesis, dan Disertasi, Bandung: ALFABETA. 